International Journal of Engineering \& Technology, $7(2.5)(2018) 53-57$
International Journal of Engineering \& Technology
SPC
Website: www.sciencepubco.com/index.php/IJET
Research Paper

\title{
Revitalization Model The Role of Tigo Tungku Sajarangan in Fostering Character of Children in Minangkabau Family and Its Socialization Through Website
}

\author{
Roswita Sitompul ${ }^{1}$, A Alesyanti², H Hartono ${ }^{3 *}$, Ansari Saleh Ahmar ${ }^{4}$ \\ ${ }^{I}$ Faculty Law, Universitas Islam Sumatera Utara, Medan, Indonesia \\ ${ }^{2}$ Department of Criminal Law Faculty of Law Science, Universitas Muhammadiyah Sumatera Utara, Medan, Indonesia \\ ${ }^{3}$ Department of Computer Science, STMIK IBBI, Medan, Indonesia \\ ${ }^{4}$ Department of Statistics, Universiti Negeri Makassar, Makassar, Indonesia \\ Corresponding author E-mail: hartonoibbi@gmail.com
}

\begin{abstract}
Globalization is not a process of depriving identity, but a process for maintaining the identity of a nation. Maintenance does not mean to close themselves from the influence of foreign culture. The values contained within a culture must have the ability to adapt and adapt to other cultures through a selection process. Considering the social phenomenon that is happening in the daily life of Minangkabau society, implied the roots of cultural values, especially the value of characters, began to erode in the education of children in the family. The value of the character is almost no longer reflected in the daily life of Minangkabau youth. In fact there is an extreme statement that is often expressed by adat leaders, that at the level of the concept of Minangkabau human still densely, but not in line with the level of behavior. Changes in behavior of the younger generation seems to have tercerabut from the roots of culture.Starting from the above phenomenon, the researcher wanted to re-question the tasks and functions of the tuahku sajar tungku, which had been instrumental in providing character values for the children and nephew in Minangkabau, but slowly the task began to shift and rely on the parents alone. The question that arises here is why customary law no longer raises the responsibility of planting the value of character to the tuah kuung sangan, what factors lead to waning the spirit of character values in the education of children in the family, and how the model design that can be used as a reference for the effort to re-revitalize the role of tigo stoves in helping parents in instilling character values on Minangkabau family. This model is expected to be known to many people through socialization by using the website.
\end{abstract}

Keywords: Revitalization, Character, Tigo Tungku Sajarangan, Website.

\section{Introduction}

Boel et al.[1] examines the use of one of the language tools of socialization in a family speech, note. A comment is a statement with explicit or implicit purpose to influence a conversation partner to behave or speak in a particular way. Ejick and Bargeman [2]research give the result that There were no signs of a general decline in the impact of the social environment, with some exceptions in terms of gender and income. The effects of education and age often become larger, which confirms the idea that socialization has become a more important determinant of lifestyle. Belletich and Villareal [3] research shows the impact of contemporary technology culture and ICT on the dynamics of socialization and the process of interacting with the reality of 2-4 year olds who are active or passive consumers of digital technology. Greenfield et al. [4] had done a research that the study shows the impact of contemporary technology culture and ICT [5]-[7] on the dynamics of socialization and the process of interacting with the reality of 2-4 year olds who are active or passive consumers of digital technology.The phenomenon that occurs in the midst of society at this time, namely the number of shifts found cultural values, especially done by the younger generation. The occurrence of the shift was due to the change in their values. Changes in society can be about norms, values, patterns of behavior and stratification of society Because of the wave of globalization that gave birth to a global culture, and supported by information superhighway then elements of global culture will enter the local world with very fast and intensive[8]. The process of cultural globalization will be a threat to the culture of a nation, if previously a culture of a nation that grows isolated and developed steadily and statically, then in the open world such a situation begins to disturb. This is where the identity of a nation is needed, because it is a force that can withstand the outer elements that come. For that we need the power of humans who have a love of local wisdom, that is man who has the knowledge, keinginanan and beliefs about the efficacy of its own cultural values. Armed with that component, a nation will be able to prepare its young generation with character value capital, which is needed in the face of foreign cultural strikes. Now the question is, who holds the responsibility for planting the value of karakater in the young generation as early as possible ?. Is it only parents who have the task?, If only rely on parents, for what the value of local wisdom, which we should uphold and we maintain. Referring to the commitment of local wisdom in Minangkabau, which values have existed for a long time, and is the pride and character of its people, it is slowly beginning to erode with the existence of 
foreign cultures. Given the cause, various factors we can review[9]. Sousa et al. research shows that the media can enhancing the communication between media and its user community[10].

\section{Related Works}

In recent times, many deviant behaviors have been shown by Minangkabau society in general and Minangkabau adolescents in particular. Data taken from the Ahmad [11], among others: 1) Women become prostitutes and children become abandoned or street children. The latest data of prostitutes who were rehabilitated at Andam Dewi Solok Social House 90\% of them are Minangkabau women. 2) Street children are increasingly growing, in various public places in the cities of West Sumatra, where the goings of philosophy "the child is on the nephew guided?" Moreover, the street children are girls, on which the sustainability of this matrilineal system hung. 3) Further models of young Minangkabau adolescent clothes are normatively distant from Minangkabau culture and customs. Everywhere we can see girls dressed tight and open, not only in entertainment venues but also in public places and campuses. This condition reflects the loosening of family and social controls. And not an institution or a women's organization that is capable of capturing (raiding bikini / tight clothing) if there is only a discourse. Then where is the location of Adat Basandi Syara'-Syarak Basandi Kitabullah? That the Minangkabau woman was ka unduang-unduang ka Madinah ka payuang pennant ka sarugo. 4) One more thing the reality of Minangkabau women today is the increasing of violence and rape of girls. Even the alleged violence against women and children in West Sumatra in 2005 was ranked highest in Indonesia. Good fornication, sexual harassment, torture and rape, generally children aged 4-12 years (under age). Even worse, most of the perpetrators are those who are close to the victim. If seen further generally occur in the nearest environment such as at home, playground, school and even a place to study. 5) The large number of Minangkabau masakan terutma teenagers who no longer know the customs, manners, and manners in Minangkabau adat. 6) And various other irregularities that are not mentioned and / or have become public secrets known to the public and we just "turn a blind eye" on this issue. From these data, of course we can see the "bobroknya" Minangkabau culture and custom today. 7) The shift in cultural values of Minangkabau into a "westernized" cultural value that "God" is freedom. But what kind of freedom? That freedom is free without limit. Recently a horrendous event in $\mathrm{Pa}$ dang, West Sumatra. The plan will be held a valley that carries as much as what young Minangkabau women to use shorts as possible in public places. Fortunately, this plan was immediately "sterilized" by the Padang City Office and the Padang MUI so that undesirable things like this did not happen. In the design of the website we must care about data diversity [12] [13] and data sensitivity [14] and the quality of website[15]

A research of [16] shows that A growing number of children have access to the internet. Children are in most US homes with on-line subscriptions and in almost half the estimated number of homes with Internet access. Their access to personal computers (PCs) and the Internet is partly due to parents' view that using PCs develops children's investigative skills, critical abilities and academic potential. Observers also point out that home computers and Internet access can increase parental and child literacy and technological awareness and influence their behavior, behavior and relationships Sayuti said there are two important factors tercerabutnya value of character in the younger generation Minangkabau first: the root of the philosophical value of "adat basandi syarak, syarak basandi Kitabullah from matrilineal earth, second: function and role of tigo sanganangan strokes and tigo sapilin rope crisis : 1) the relationship of mamak (uncle) with the nephew began to widen, 2) ninik mamak less able to nurture the child's nephew, 3) alim ulama very limited ability mensiarkan teachings akhlakur karimah and teachings of Islam deeply, 4) clever clever less able to uphold the su- premacy of law, 5) too much government power over local laws, and 6) not much social role from the four martyrs in Nagari, consequently customs halls are not functioning, surau does not play a role, the field is not alive, the younger generation loses identity and identity self [17]. The stove in the true sense is where to set the pan, pot, and cauldron to produce the cooking. The stove is always supported by three buffers, so that the cooked is not spilled or not tilted. So the leadership of the tigo sajarangan stove is a symbol of strong leadership in Minangkabau society. Society is like a vessel that will ditarok on the stove, he will feel safe and secure with the power of the furnace earlier, The existence of the three elements of the leader gave birth to the tigo sapilin ropes syarakilin, customs, and laws needed Minangkabau society to achieve prosperityAdat basandi syarak, syarak basandi kitabullah, syarak mangato, indigenous mamakai, nature takambang so the teacher is the view of life of Minangkabau indigenous people. Adat and syarak see the internal structure of Minangkabau society and culture as a dynamic acculturation between local customs and the universal religion of Islam. Adat and religion for the people of Mnangkabau is a vital provision in regulating people's lives. Customary provisions become the role of society in behaving [18][19].

\section{Methodology}

The general architecture of the proposed method used is depicted in Fig. 1

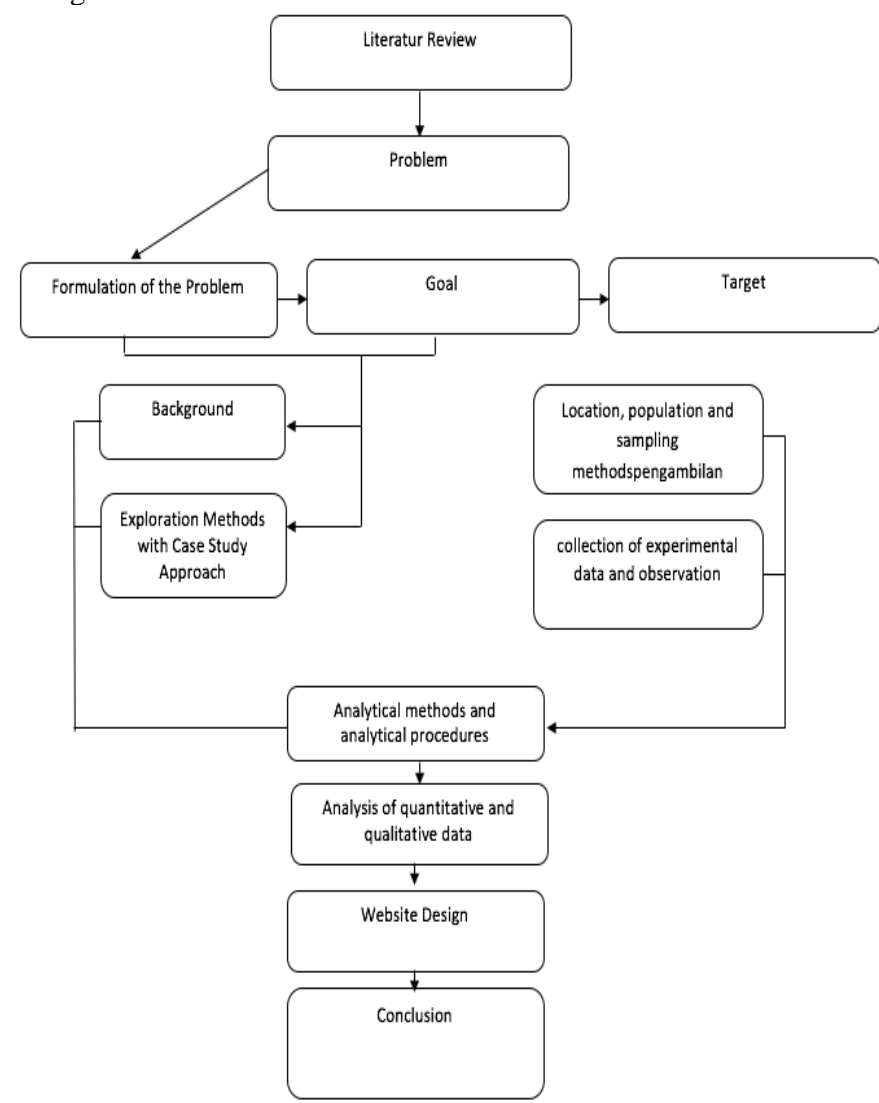

Fig. 1: The General Architecture

\subsection{Method Type}

This research started (year 1) using exploratory method (exploration). This method is fundamental and aims to obtain information, information, and data on the unknown or early data on the origin, development and role and duties of traditional leaders, namely tigo tungku sajarangan (Muhammad, 2004: 49). In the next stage, caseanalysis methods with qualitative approaches to explore and understand the meaning which some individuals or groups of people derive from social or humanitarian problems. In this case will be in the analysis, background, subject, or a particular event, and 
what role should be done by the tigo ignition furnace to revitalize the value of the character for the transformation of the child's value in the Minangkabau family. Data collection must be direct from the subject and researcher as the instrument, and conduct participant observation and in-depth interviews.Based on the data, description, roles, and case analysis, the revitalization model design is formulated, and in the 2nd year study, and in the last year will be a final model of revitalization of the role of tigo sideways in the character development of children in Minangkabau family. This model is in though through experimental studies and observation.

\subsection{Population and Sample}

The population in this study is all subdistricts in the city of Padang, which amounts to 11 districts. These populations and samples, researchers use to capture the opinion of the people of $\mathrm{Pa}$ dang City about the existence, views, expectations of the task and the role of ninik mamak, pious scholars, clever (tigo tungku sajarangan). Is their existence still needed for the continuity of planting the character from an early age to the younger generation Minangkabau. Given the size of the population, the sample used is only for customary families, with purposive sampling techniques, other questionnaire criteria are only given by parents in customary families only.

\subsection{Website Design}

The design of socialization website in this research is done by using System Development Life Cycle (SDLC) method [6], [7], [20]-[26] The SDLC Method can be seen in Fig. 2.

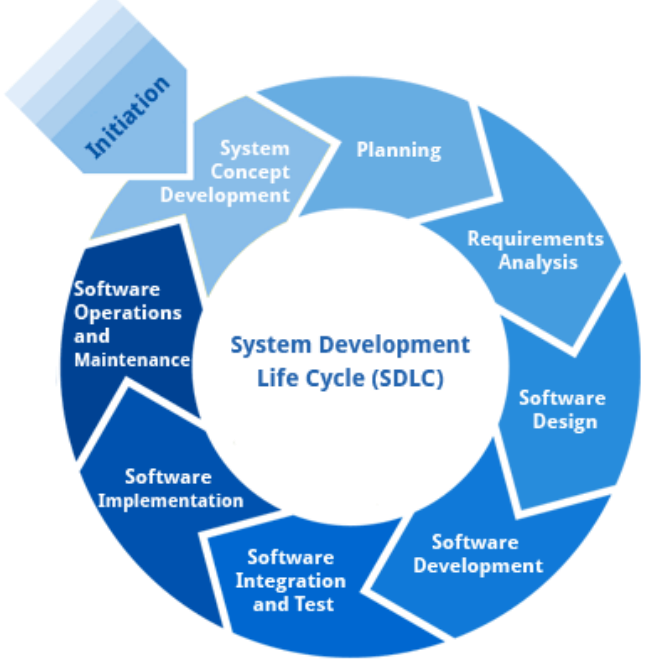

Fig. 2: SDLC Method

\section{Result and Discussion}

\subsection{Customary law regulation, about the role and responsibility of planting character value by tigo tungku sajarangan in Minangkabau}

Minangkabau customary law, loaded with the content of noble values, in the form of character values that are needed in shaping the child's personality in the family. A person's personal formation as governed by Minangkabau adat is to create a sublime and sublime personality, giving birth to an intelligent person, clever and possessing a strong mentality and personality. In restoring the existence of this faded adat into the identity of the Minangkabau community, it is necessary to revitalize the role of tuahku tungku sajar in restoring the values of the character that is in the form of unification of customary law, Islamic law, and the Law. The Design of the Customary Law Regulation is called Tali Tiga Sepilin that can be seen in Fig. 3 .

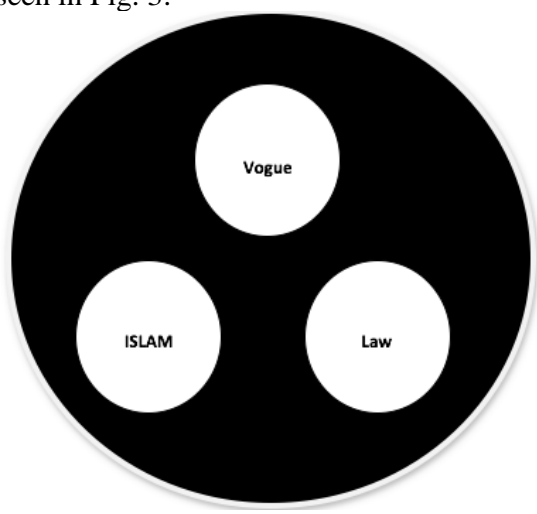

Fig.3 : Tali Tiga Sepilin

Furnace in the true sense is where to set the pan, pot, and cook to produce the dish. The stove is always three, no two, so that the cooked is not spilled or not tilted. So the leadership of the tigo sajarangan stove is a symbol of strong leadership of Minangkabau society. Society likened to a vessel that will be placed on the stove, he will feel safe and secure with the power of the tigo sajar stove earlier. The existence of the three elements of the leader gave birth to the tigo sapilin rope, the syarak, adat and the laws needed by the Minangkabau people to achieve their welfare. The results show that the role of these three elements has undergone many shifts or degradation, which means that the transformation of adat social moral values is more dominated by parents' education in the family. The shift of function and duty of tigo sangan furnace in the re-functioning of social moral values of adat in family life.

\subsection{Factors that lead to waning of character values in the education of children in Minangkabau families}

Based on the results of the research, there are several factors causing waning of character values in children in Minangkabau families: 1) poor understanding of the concept of adat basandi syarak, syarak basandi Kitabullah, 2) a materialistic, hedonistic and secularistic life culture for some Minangkabau people, 3) lack (4) reduced leadership of tigo sangan stove, and 5) religious education curriculum in surau, where Minangkabau children study religion, now more dominated by formal education science, and put aside character building.

\subsection{Design a model that can be used as a ref- erence for the effort to re-revitalize the role of Tigo Tungku Sajarangan in helping parents to instill character values in Minangkabau family}

In Minangkabau in the revitalization of character education in children in the family can not be separated the influence of Tigo Tungku Sajarangan. The necessity of the revitalization of adat is in line with the notion of adat to inherit and preserve the custom, in the sense of preserving Minangkabau custom and culture so that it is still functioning in real life, while the latter means keeping it still visible, known by the children and grandchildren of the tribe other nations. The Minangkabau culture contains a highly urgent charge of character values to be transformed to the education of children in the family. The character values can be formulated in the model that can be seen in Fig. 4. 


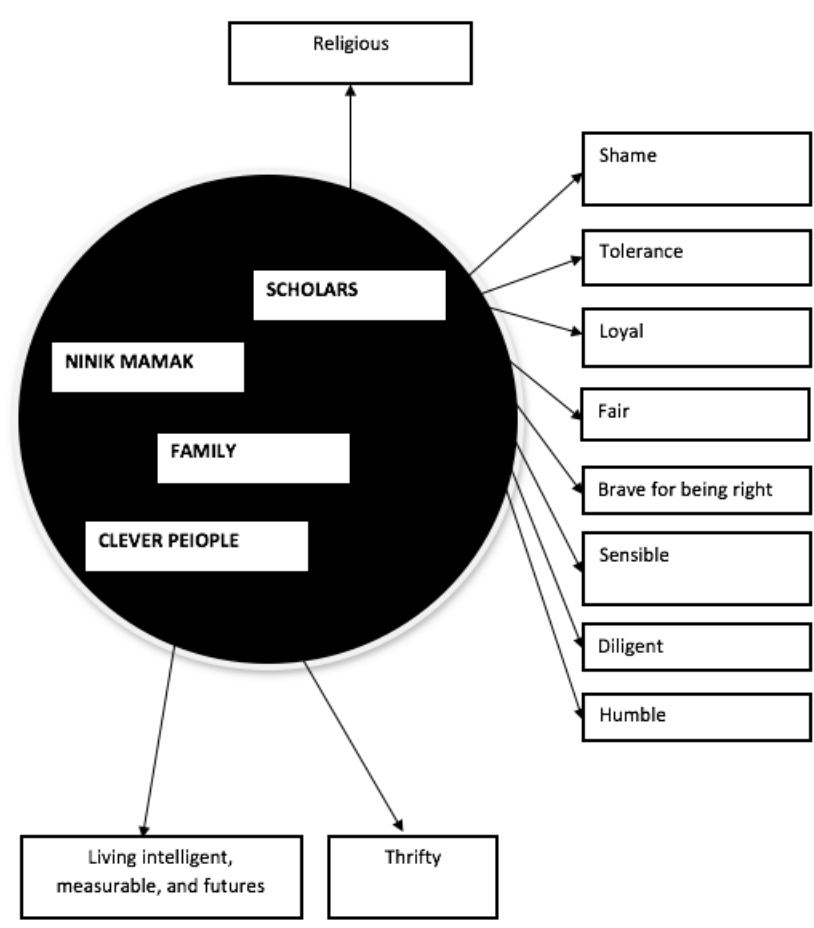

Fig. 4: The role of Tigo Tungku Sajarangan

Now what are the roles of the three Furnaces above, 1) Ninik mamak plays the role of the nephew and community in the nagari, while in the family, the ninik mamak switches to a mamak whose job is to "take care of his sisters, guide his nephews, literature "(Singgalang, September 10, 1989). The task of ninik mamak in Minangkabau further is to guard library treasures, help the economy of nephew children, solve social problems and morals, go to ask places and berberita berberita, meaning if there are difficulties faced by children nephew and his sister mamak must give guidance and advice; 2) Scholars, is the functional religion in society. The function of the clerical scholars is primarily as an inheritance of the inner birth, the bright light in the nagari, the counselor of the child and the nephew, the light of the way of the world and the hereafter, knowing lawful and haram, lawful and vanity. The scholars should seek to encourage the people to avoid all forms of disobedience, to strive at any place, to know the sickness of society and to seek a solution, and to give consideration to the penghulu to make decisions in the field of religion; and last 3) Clever People, who plays a solid and funnel fence within the village, customary and religious fencing, child fencing and nephews, balustrades and mosques, rice paddies and fields, shelter and shame, prevents people from escaping adat teachings and religion, protecting adat so that it is still used as a moral teaching and character for the child's nephew and society. Revitalization of the character values of children in Minangkabau families can be pursued through various efforts, namely by building togetherness, confirmation, openness, mutual trust, democratization, consistency, deliberation and exemplary parent. The revitalization of Minangkabau adat character values is not enough through education in the family alone, but the role of the leaders of adat leaders (tigo sanctuary tajarangan) is decisive, by maintaining the existing functions but transferring the responsibility in the implementation, such as cleverly bear some of the functions of ninik mamak and vice versa duties and responsibilities cleverly switch to ninik mamak or alim ulama.

\subsection{Website Design}

The Use Case Diagram of the website design can be seen in Fig. 5.

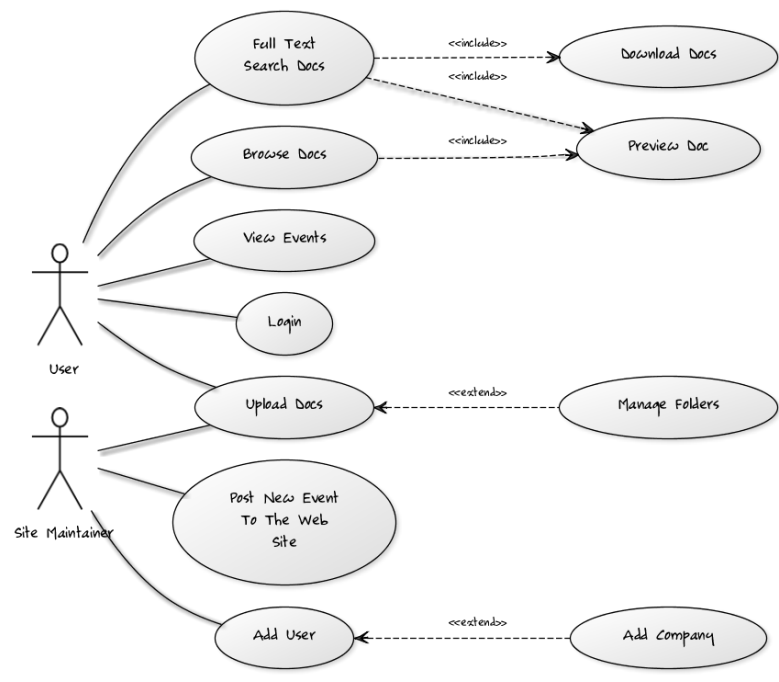

Fig. 5: Use Case Diagram

\section{Result and Discussion}

Revitalization of the character values of children in Minangkabau families can be pursued through various efforts, namely by building togetherness, confirmation, openness, mutual trust, democratization, consistency, deliberation and exemplary parent. The revitalization of Minangkabau adat character values is not enough through education in the family alone, but the role of the leaders of adat leaders (tigo sanctuary tajarangan) is decisive, by maintaining the existing functions but transferring the responsibility in the implementation, such as cleverly bear some of the functions of ninik mamak and vice versa duties and responsibilities cleverly switch to ninik mamak or alim ulama.The result of the research also shows that there is no effect of tigo sajar stove in planting some aspect of value, therefore revitalization of character value is very urgent done by tungku kakung sajar. This does not mean that the value is not there anymore, but the function of planting those values has shifted to father and mother. Ninik mamak, Scholars, and clever scholars should always give counseling to parents, Local Government, and last return the function surau as a forum for religious counseling, mental coaching, morals, moral values and character.

\section{Conclusion}

The conclusion of this research are as follows. First, the Role of Tigo Furnace Model Sajarangan is effective in fostering the character of the child in the Minangkabau family. Secondly, the existing role model of Tigo Tungku Sajarangan can be actualized into the life of the young generation through adjustment to the current conditions. Third, the role of Information Technology especially important Website in the socialization of Tigo Tungku Sajaragan model so that it can be known by many people in Minangkabau, Indonesian Society, and International in general.

\section{References}

[1] B. De Geer, T. Tulviste, L. Mizera, and M. T. Tryggvason, "Socialization in communication: Pragmatic socialization during dinnertime in Estonian, Finnish and Swedish families," $J$. Pragmat., vol. 34, no. 12, pp. 1757-1786, 2002.

[2] K. van Eijck and B. Bargeman, "The changing impact of social background on lifestyle: 'culturalization' instead of individualization?,” Poetics, vol. 32, no. 6, pp. 447-469, Dec. 2004

[3] O. Belletich and M. P. de Villarreal, "Knowledge of the Natural and Social Environment in ICT Consumer Children," Procedia Soc. Behav. Sci., vol. 237, pp. 164-168, Feb. 2017.

[4] P. M. GREENFIELD, L. CAMAIONI, P. ERCOLANI, L. WEISS, 
B. A. LAUBER, and P. PERUCCHINI, "Cognitive Socialization by Computer Games in Two Cultures: Inductive Discovery or Mastery of an Iconic Code?," p. 27.

[5] J. Suyono, A. Sukoco, M. I. Setiawan, S. Suhermin, and R. Rahim, "Impact of GDP Information Technology in Developing of Regional Central Business (Case 50 Airports IT City Development in Indonesia)," in Journal of Physics: Conference Series, 2017, vol. 930, no. 1 .

[6] A. Rahman, U. Mulbar, and A. S. Ahmar, "Development of Webbased Logical Thinking Abilities and Android as an Alternative Solution for Research Instruments," J. Phys. Conf. Ser., vol. 1028, no. 1 , p. $012168,2018$.

[7] Rusli, N. Noni, N. Ihsan, and A. S. Ahmar, "The Development of Research Management Information System Based on Web at Universitas Negeri Makassar," J. Phys. Conf. Ser., vol. 1028, no. 1, p. 012050, 2018.

[8] R. Rahim et al., "INA-Rxiv: The Missing Puzzle in Indonesia's Scientific Publishing Workflow," J. Phys. Conf. Ser., vol. 1007, no. 1, p. 012032, Apr. 2018.

[9] R. Sitompul, "NORMATIVE ANALYSIS OF LAW NO 23 YEAR 2002 ABOUT CHILDREN'S PROTECTION IN RELATION TO CHARACTERED LEARNING AT PRIMARY SCHOOL IN MEDAN, INDONESIA," no. 10, p. 8, 2017.

[10] A. A. Sousa, P. Agante, and L. B. Gouveia, "Communication Model for Sports Media Web Portals,” AASRI Procedia, vol. 8, pp. 44-49, 2014.

[11] divo | 6 D. 2008 pukul 07:54, PENYIMPANGAN PERILAKU PEMUDA MINANGKABAU DI PANDANG DARI SEGI BUDAYA DAN ADAT MINANGKABAU. 2008.

[12] Hartono, O. S. Sitompul, E. B. Nababan, Tulus, D. Abdullah, and A. S. Ahmar, "A new diversity technique for imbalance learning ensembles," Int. J. Eng. Technol., vol. 7, no. 2, pp. 478-483, 2018.

[13] O. S. Sitompul and E. B. Nababan, "Optimization Model of K Means Clustering Using Artificial Neural Networks to Handle Class Imbalance Problem," IOP Conf. Ser. Mater. Sci. Eng., vol. 288, p. 012075, Jan. 2018.

[14] H. Hartono, O. S. Sitompul, T. Tulus, and E. B. Nababan, "Biased support vector machine and weighted-smote in handling class imbalance problem," Int. J. Adv. Intell. Informatics, vol. 4, no. 1, pp. 21-27, Apr. 2018.

[15] D. Abdullah et al., "A Slack-Based Measures for Improving the Efficiency Performance of Departments in Universitas Malikussaleh," Int. J. Eng. Technol., vol. 7, no. 2, pp. 491-494, Apr. 2018.

[16] S. Grossbart, S. M. Hughes, S. Pryor, and A. Yost, "Socialization Aspects of Parents, Children, and the Internet," ACR North Am. $A d v$., vol. NA-29, 2002.

[17] S. Sayuti, "Kumpulan Kertas Kerja dan Hasil Rumusan Mubes III Gebu Minang," 2001.

[18] A. Alesyanti, "Education Philosophy and Media Model Based on Heterogeneity Culture in North Sumatera Indonesia," Adv. Sci. Lett., vol. 24, no. 4, pp. 2823-2825, 2018.

[19] A. Alesyanti, Revitalisasi Nilai Moral Sosial Adat Minangkabau Dalam Kehidupan Keluarga. Bandung: UPI.

[20] D. Napitupulu et al., "Analysis of Student Satisfaction Toward Quality of Service Facility," J. Phys. Conf. Ser., vol. 954, no. 1, 2018.

[21] M. Setiawan et al., "E-Business, Airport Development and Its Impact on the Increasing of Information of Communication Development in Indonesia," J. Phys. Conf. Ser., vol. 1007, no. 1, p. 012046, Apr. 2018.

[22] D. Napitupulu, M. Syafrullah, R. Rahim, D. Abdullah, and M. Setiawan, "Analysis of user readiness toward ICT usage at small medium enterprise in south tangerang," J. Phys. Conf. Ser., vol. 1007, no. 1, p. 012042, Apr. 2018.

[23] K. Adiyarta, D. Napitupulu, R. Rahim, D. Abdullah, and M Setiawan, "Analysis of e-learning implementation readiness based on integrated elr model," J. Phys. Conf. Ser., vol. 1007, no. 1, p. 012041, Apr. 2018.

[24] F. A. A. Fauzy et al., "Registration System and UTM Games Decision Using the Website Application," Int. J. Eng. Technol., vol. 7, no. 2.2, pp. 45-47, 2018.

[25] F. A. A. Fauzy et al., "Registration system and UTM games decision using the website application," Int. J. Eng. Technol., vol. 7, 2018.

[26] A. S. Ahmar and R. Jefri, "The development of information system of IT-Based scientific works to improve the quality of the students' final project publication," J. Phys. Conf. Ser., vol. 1028, no. 1, p. 012047, 2018. 